\title{
Analysis of Performance of Chickpea (Cicer Arietinum) Variety under Chemical Fertilizers use in Bhairahawa, Nepal
}

\author{
Suresh Simkhada* \\ Agriculture and Forestry University, Nepal \\ *Corresponding author: Suresh Simkhada, Agriculture and Forestry University, Nepal
}

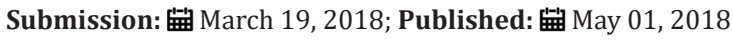

\begin{abstract}
Diagnostic research on performance of Chickpea (Cicer arietinum) variety under chemical fertilizers use was conducted in IAAS farm of Paklihawa Campus, Nepal to reveal both short term and potential long-term problems in chick pea cultivation in Nepal and evaluate the yield of check pea under chemical fertilizers use. There were three replications of the treatments. The treatments were found significantly different for vegetative as well as yield parameters. The issues for chickpea were found to include pest and diseases, mid-season moisture stress and weed problems. Optimum seedling rate is one of the most important production factors for higher grain yield as well as for quality crop. Indiscriminate use of seed and fertilizer not only increases the production cost but usually decrease yield. The overall performance of check pea was found better under chemical fertilizer application though pest infestation was high.
\end{abstract}

Keywords: Diagnostic; Check pea; Yield parameters; Production factor; Indiscriminate; Infestation

\section{Introduction}

Climate refers to the average weather conditions in a place over Chickpea (Cicer arietinum L.) commonly known as gram or Bengal gram is one of the important pulse crops of Nepal. It is a winter season crop covering 9274 ha area with the production of $9408 \mathrm{Mt}$. in Nepal [1]. It is second most important pulse crop after lentil and predominantly grown under rain fed conditions. The yield levels on the cultivator's fields are very low mainly because improved production technology is not used. The national productivity of chickpea is thus only $990 \mathrm{~kg} / \mathrm{ha}$.

Check pea was leading pulse crop of Nepal until early 1980's. However, the trend reversed and the production of check pea came to fifth place after Lentil, grass pea, black gram and pigeon pea. The descending trajectory of check pea was due to its susceptibility to several diseases and insect pest. Chickpea is mainly used for human consumption as well as for feeding animals. It is used as 'Dal' in split form. Whole fried or boiled seeds of chickpea are also eaten. Husk and bits of 'Dal' are used as nutritious feed for animals. Green leaves of chickpea are used as vegetable (sag). Grains are also used as vegetable (chhole). Flour is used in the preparation of various sweets. It is also mixed with wheat flour for 'chapati' making. Chickpea can also be used as green fodder. Its straw is an excellent fodder for animals.
The application of cattle dung manure (FYM) + vermincompost give highest seed yield of chickpea compared to other organic combination [2]. Increase in grain yield of chickpea with the application of various nutrients could be due to improvement in plant growth and yield attributes such as pods per plant, seeds per pod and leaf area index [3]. Application of farmyard manure and poultry manure in combination with inorganic NPK fertilizers show positive effect on chickpea plant height, number of branches/ plant, number of pods/plant and seed index. The growth and yield of chickpea significantly increases with the collective application of chemical fertilizers and organic manures [4].

\section{Methodology}

The research was conducted in the Agronomy field IAAS, Paklihawa Campus Paklihawa, Rupandehi, Nepal. The late season variety of chickpea was used in the research. There were two treatments and three replications of the treatments. For the evaluation of the yield of chickpea with different treatments responses at given environmental condition, check pea was planted in 6 plots of each $4 \mathrm{~m} \times 3 \mathrm{~m}$. The chickpea was sown with the use of recommended fertilizers above and maintained cultural practices. Seeds free from seed borne diseases and seeds of weeds, viable and certified seed were used for the cultivation. 88 gram of seed for 
$4 \times 3 \mathrm{~m}^{2}$ plot maintaining $40 \mathrm{~cm}$ row distance and $8 \mathrm{~cm}$ plant distance with 2 seeds per hill. The depth of sowing was maintained $5 \mathrm{~cm}$ [5]. Fertilizer dose 20:40:20 NPK kg/ha was applied in three plots Table 1: Table shows fertilizer dose for $4 \times 3 \mathrm{~m}^{2}$ plot. while in three plots only recommended dose (6ton/ha) of FYM was applied (Table 1) (Figure 1).

\begin{tabular}{|c|c|c|}
\hline S.no & Fertilizer & Dose(gm) \\
\hline 1 & Urea & 13 \\
\hline 2 & Diammonium phosphate & 104 \\
\hline 3 & Murate of potash & 40 \\
\hline
\end{tabular}

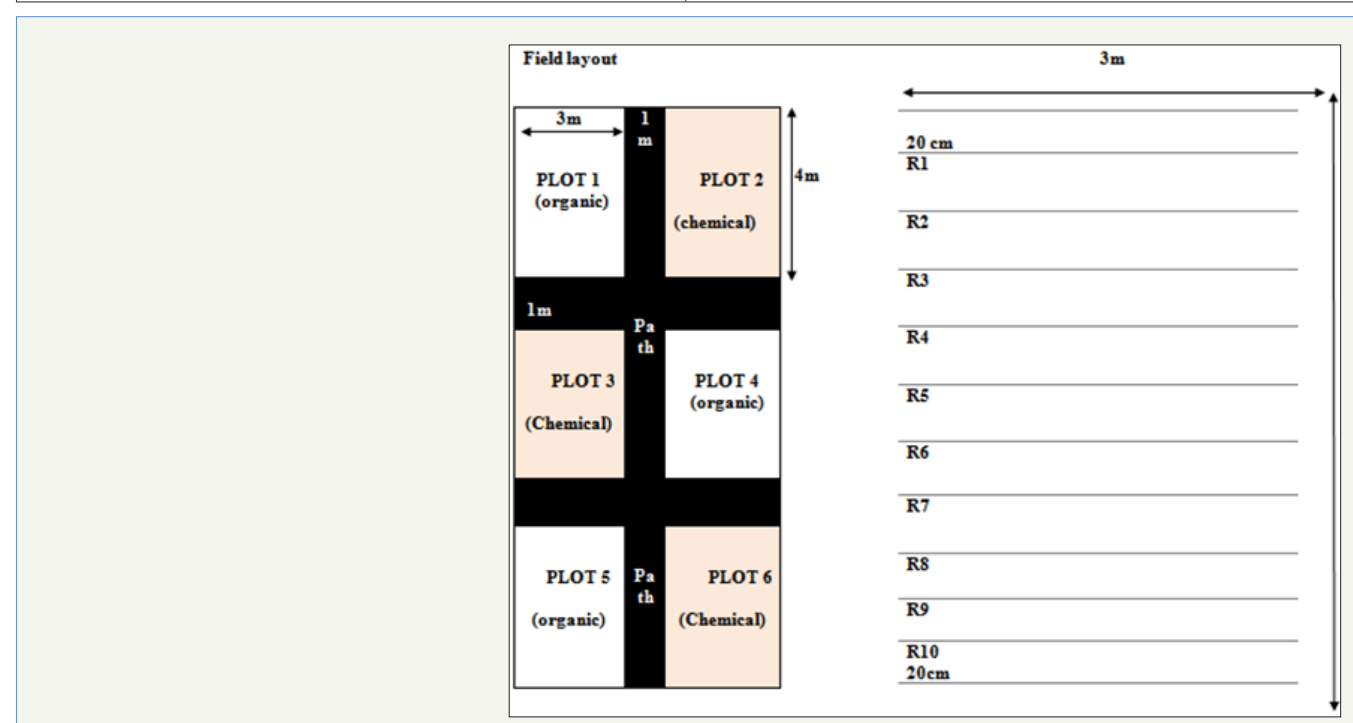

Figure 1:

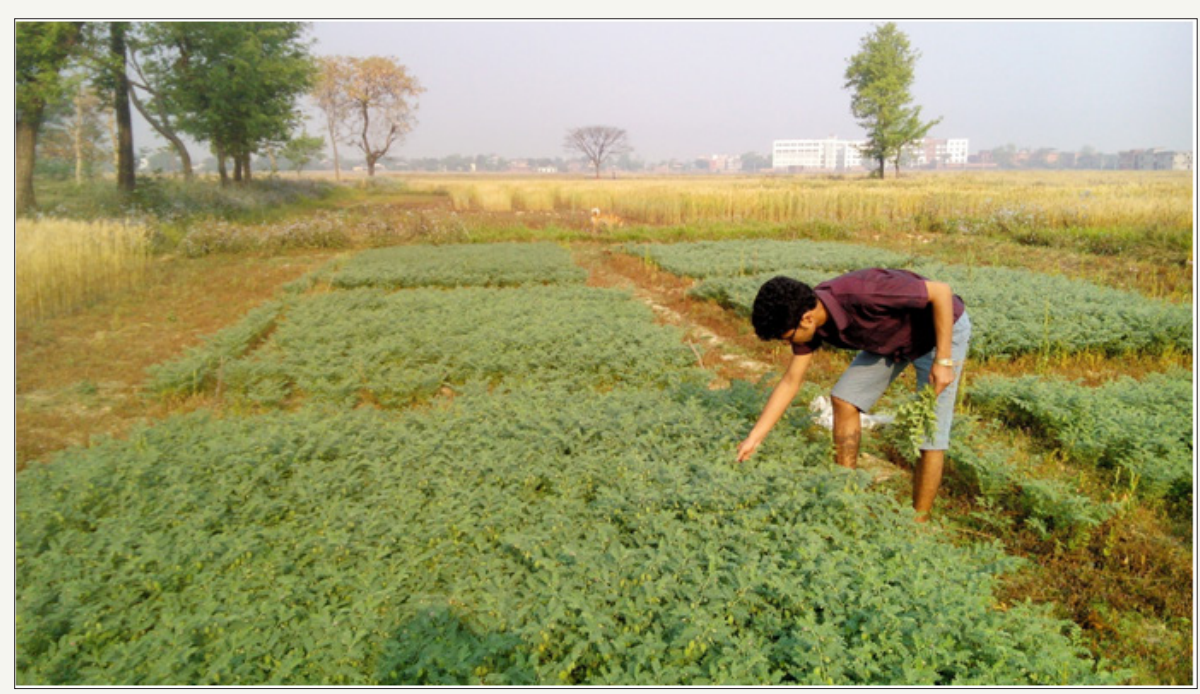

Figure 2:

The weeds were prominently spread all over the plot from early stage of growth of chickpea. Some common weeds grown were Chenopodium album, Vicia sativa, Cynodon dactylon, Anagalis arvensis and Halhale. No chemicals were used and manual weeding was done to control weeds (Figure 2).

Following yield attributing characters were observed and analyses were done using MS-excel and SPSS tools.
a) No of plants per unit area
b) Number of primary branches (NPB) per plant
c) No of pods per branch (NP)
d) Number of grains per pod
e) Test weight (1000 grain weight)
f) Leaf area index 
i. $\quad$ Test weight $(1000$ seed $w t)=.\ldots . . . \mathrm{gm}$

ii. Average no. of plants $/ \mathrm{m} 2=\frac{1}{\text { spacing }(\mathrm{m} 2)} \times$ no.of seed per hill $=\frac{1}{0.4 \times 0.08} \times 2$ $=62$

iii. Total yield/plot (12 m2)

iv. (Avg. no of plants per $m 2 \times$ no. of branches per plant $\times$ No. of pods per branch $\times$ test w. of seed $\times 12)$ $1000 \times 1000$

V. $\quad=\frac{62 \times 4 \times 8.5 \times \ldots \ldots . . .12}{1000 \times 1000} \mathrm{~kg}$

vi. Yield $/ \mathrm{ha}(\mathrm{Kg} / \mathrm{ha})=\ldots \ldots . . \times(10000 / 12)=\ldots \ldots . \mathrm{Kg}$ vii. Leaf area index $(\mathrm{LAI})=\frac{\text { Leaf area }}{\text { Land area }}$

viii. Harvest index $(\mathrm{HI})=\frac{\text { Leed yield }(\mathrm{g})}{\text { Biological yield }(\mathrm{g})} \times 100$

\section{Result and Discussion}

The average plant height and no. of branches per plants are presented in (Table 1). The average plant height was found to be $15.09 \mathrm{~cm}$ under chemical fertilizer application and $14.5 \mathrm{~cm}$ under normal condition of FYM application. The no. of branches per plant was found 5 and 4 under chemical fertilizer application and FYM application respectively (Table 2).

Table 2: Average plant height and no. of branches per plant.

\begin{tabular}{|c|c|c|c|c|}
\hline Characters & 30 DAS & 60 DAS & 90 DAS & 13.4 \\
\hline Chemical fertilizers & 3.39 & 7.03 & 4 & 15.09 \\
\hline Average plant height (cm) & 2 & 3 & 13 & 14.5 \\
\hline Average no. of branches & 3.5 & 7 & 4 & 4 \\
\hline FYM & 2 & 3 & \\
\hline Average plant height (cm) & & & & \\
\hline Average no. of branches & & & & \\
\hline
\end{tabular}

Source: Field Survey, 2015.

Figure 3:

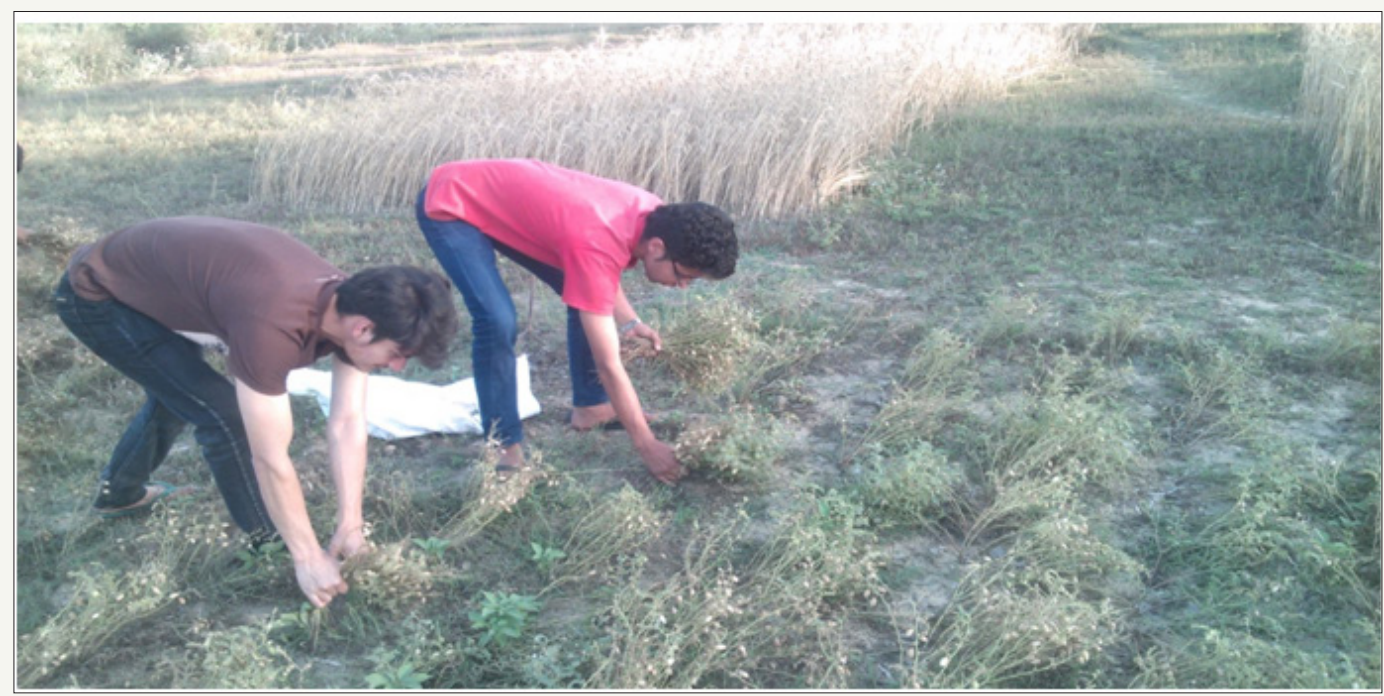

Table 3: Average number of leaves and leaf area per plot.

\begin{tabular}{|c|c|c|}
\hline Character & \multicolumn{2}{|c|}{ Measurements } \\
\hline & Chemical fertilizers & 2 \\
\hline Av. no of rachis/branches & 2 & 5 \\
\hline No. of larger leaves/ rachis & 5 & 3 \\
\hline No. of smaller leaves/rachis & 3 & $10.2 \mathrm{~cm}^{2}$ \\
\hline Area of large leaf & $10.5 \mathrm{~cm}^{2}$ & $4.35 \mathrm{~cm}^{2}$ \\
\hline Area of small leaf & $4.5 \mathrm{~cm}^{2}$ & $1024.8 \mathrm{~cm}^{2}$ \\
\hline Av. total leaf area per plot & $1320 \mathrm{~cm}^{2}$ & 3.20 \\
\hline LAI & 4.13 & \\
\hline
\end{tabular}

Source: Field Survey, 2015. 
Table 4: Average yield and HI per plot.

\begin{tabular}{|c|c|c|}
\hline Characters & Chemical fertilizers & FYM \\
\hline Biological yield (gm) & $2110 \mathrm{gm}$ & $3020 \mathrm{gm}$ \\
\hline Economic yield (gm) & $410 \mathrm{gm}$ & $300 \mathrm{gm}$ \\
\hline Harvesting index (HI) & $19.43 \%$ & $16.48 \%$ \\
\hline Yield $/ \mathrm{m}^{2}$ & $34.16 \mathrm{gm}$ & $25 \mathrm{gm}$ \\
\hline
\end{tabular}

Source: Field Survey, 2015.

Average no. of leaves, leaf rea and leaf area index (LAI) under different treatment condition is presented in table below (Table 2). Though average total leaf area and leaf area index was found higher under chemical fertilizers use due to large sized leaves, the average no. of leaves was found equal in both treatments [6] (Figure $3)$. Higher LAI of 4.13 was observed under chemical fertilizers use than under FYM use i.e. 3.20 (Table 3). The average yield and harvesting index under two conditions is presented in (Table 3). Higher harvesting index (HI) was obtained under chemical fertilizer use than in FYM use. Average yield of $34.16 \mathrm{gm} / \mathrm{m} 2$ under use of chemical fertilizers and $25 \mathrm{gm} / \mathrm{m}^{2}$ under FYM use was observed (Table 4).

\section{Conclusion}

The research study was aimed at finding performance of the check pea under different conditions. The result from this research shows that the overall performance of check pea was found better under chemical fertilizer application though pest infestation was high under chemical fertilizer application. The leaf area index under NPK application was found 4.13 compared to 3.2 under FYM application [7]. The average yield and harvesting index under chemical fertilizer application are $410 \mathrm{gm}$ and $19.43 \%$ respectively. Higher harvesting index (HI) and average yield suggest check pea perform better under chemical fertilizer application than in FYM [8-9].

\section{References}

1. (2014) Krishi Diary. AICC, Kathmandu, Nepal.

2. Shukla M, Patel R, Verma, Rajhans, Deewan, et al. (2013) Effect of Bio-
Organics and Chemical Fertilizers on Growth and Yield of Chickpea (Cicer arietinum L.) Under Middle Gujarat Conditions. Vegetos An International Journal of Plant Research 26(1): 183-187.

3. Khan M, Qureshi A (2001) Path coefficient and correlation analysis studies on the variation induced by gamma irradiation in M1 generation of chickpea (Cicer arietinum L). Journal of Biological Sciences 1(3): 108110.

4. Sohu I, Gandahi A, Bhutto G, Sarki M (2015) Growth and yield maximization of chickpea (Cicer arietinum) through integrated nutrient management applied to rice-chickpea cropping system. Sarhad Journal of Agriculture 1(2): 131-138.

5. Bahl P (1983) Performance of tall chickpea genotype under normal and late sown condition. International Chickpea News Letter 8-9.

6. Reddy N, Ahlawat I (1998) Response of chickpea genotypes to irrigation and fertilizers under late sown conditions. Indian Journal of Agronomy 95-101.

7. Singh A, Saha J, Gosh P (2008) Effect of nutrient management practices on soybean (Glycine max)-chickpea (Cicer arietinum) cropping systems for improving seed yield, quality and soil biological health under rainfed condition. Indian Journal of Agriculture Science 78(6): 485-489.

8. Tolanur S (2008) Integrated effect of organic manuring and inorganic fertilizer $\mathrm{N}$ on yield and uptake of micronutrients by chickpea in vertisol. Legume Research An International Journal 31(3): 184-187.

9. Verma C, Yadav R, Singh I, Singh A (2009) Physiological traits and productivity of rainfed chickpea in relation to urea spray and genotypes. Legume Research An International Journal 32(2): 103-107.
Creative Commons Attribution 4.0 International License

For possible submissions Click Here

\section{Submit Article}

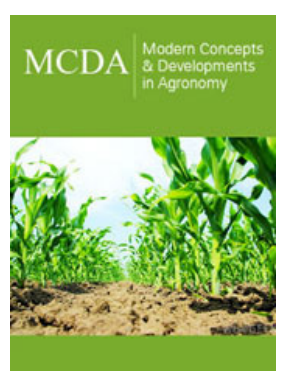

Modern Concepts \& Developments in Agronomy

\section{Benefits of Publishing with us}

- High-level peer review and editorial services

- Freely accessible online immediately upon publication

- Authors retain the copyright to their work

- Licensing it under a Creative Commons license

- Visibility through different online platforms 